\title{
The Use of Social Networking Sites among Malaysian University Students
}

\author{
Afendi Hamat (Corresponding author) \\ Pusat Pengajian Bahasa dan Linguistik, FSSK \\ 43650 UKM Bangi, Selangor, Malaysia \\ Tel: 603-8921-6546_E-mail: afendihamat@gmail.com \\ Mohamed Amin Embi \\ Fakulti Pendidikan, UKM \\ 43650 UKM Bangi, Selangor, Malaysia \\ E-mail: m.amin@ukm.my \\ Haslinda Abu Hassan \\ Fakulti Pendidikan, UKM \\ 43650 UKM Bangi, Selangor, Malaysia \\ E-mail: ha_hassan99@yahoo.com
}

Received: January 17, 2012 Accepted: January 29, 2012 Published: April 19, 2012

doi:10.5539/ies.v5n3p56

URL: http://dx.doi.org/10.5539/ies.v5n3p56

\begin{abstract}
Social networking sites (SNSs) have increasingly become an important tool for young adults to interact and socialize with their peers. As most of these young adults are also learners, educators have been looking for ways to understand the phenomena in order to harness its potential for use in education. This is especially relevant in Malaysia where SNSs are popular among the youths, yet there is little data available to describe patterns of use for the wider segment of the target population. This study presents the results of a nationwide survey on tertiary level students in Malaysia. The results show that SNSs penetration is not at full $100 \%$ as initially assumed. The respondents spend the most time online for social networking and learning. The results also indicate that while the respondents are using SNS for the purpose of informal learning activities, only half (50.3\%) use it to get in touch with their lecturers in informal learning contexts. The respondents also reported spending more time on SNS for socializing rather than learning and they do not believe the use of SNS is affecting their academic performance.
\end{abstract}

Keywords: Online social networking, Informal learning, Formal learning, Internet use

\section{Introduction}

The Internet and the World Wide Web are initially designed to move data and information from one location to another in a reliable and most efficient manner. The idea of 'sharing' at the time was worded in the form of work and research documents essential to the few who made use of the technology. After almost 20 years since Dr. Barnes-Lee created the web, the idea of sharing has taken on a whole new dimension. The success and popularity of social networking sites show that the idea of online sharing has been successfully taken to the social and personal level. The sharing of information from the most important to the most mundane ones could now be done in any digital forms: documents, photos and videos. Although some may see problems and express concerns with privacy (and justifiably so), it is undeniable that social networking is hugely popular and is here to stay.

The use of social networking by students opens up a great opportunity for educational researchers. The literature and anecdotal evidences seem to suggest that learners spend a lot of time on social networking sites. This expenditure of resources and more importantly, time, on online social activities provides an insight into the online behavior and preferences of young adults i.e. learners at tertiary education institutions. Understanding their perceptions of online social networking will provide great benefits to academic researchers as their preferences for online social activities 
could be seamlessly integrated into their learning experiences.

However, the desire to employ the latest socio-technological phenomenon must be tempered by the fact that much is yet to be known and understood about young adults and social networking sites (SNSs) especially in relation to SNSs' viability as a medium for learning. This is especially true in Malaysia where there is little data that could be used to illuminate any patterns of SNSs use for the larger population and guide more focused research on SNSs in education. While many educators and researchers would attest to the potentials of SNSs for learning, there are also those who argue that young adult learners view and use SNSs as a platform for socializing more than learning. This paper presents the results of a nationwide survey carried out among university students in institutions of higher learning in Malaysia to discover their views and use of SNSs especially for the purpose of informal learning.

\section{Literature Review}

Since their introduction, these SNSs have attracted a huge following among teenagers and also university students (Lenhart \& Madden, 2007; Salaway \& Caruso, 2008). As such, it is not surprising to find SNSs making its way into the educational environments with many claiming that these social applications have even more potential to further improve learning and sharing of information among learners and teachers (Ferdig, 2007; Maloney, 2007; Pence, 2007; Simoes \& e Gouveia, 2008). SNSs are becoming prevalent in the educational context that many educators are already exploring ways in which these tools can be used for teaching and learning (Schwartz, 2009; boyd \& Ellison, 2007; Selwyn, Crook, Carr, Carmichael, Noss \& Laurillard, 2008). Furthermore, many reports have come to light in the last few years which have accented the extent to which newer technologies are becoming increasingly entrenched in the lives and educational experience of the students of today (Jones \& Madden, 2002; Kvavik \& Caruso, 2005; Selwyn et al., 2008; Salaway \& Caruso, 2008).

Madge, Meek, Wellens \& Hooley (2009) conducted a research using an online survey among first year students ( $\mathrm{n}=$ 213) of a British university focusing on Facebook. The findings showed that Facebook is mainly used as a 'social glue' that helped these students to settle into their university life and the students mainly thought of Facebook's use for social reasons and not for formal teaching purposes; nevertheless, the students did sometimes use it for informal learning purposes such as the micro management of their life as a student in university. This finding is similar to the study by Daalsgard (2008) who found that students were using SNSs as a form to facilitate 'transparency' between students, a way in which they get insights into each others' work, ideas and creations. However, the 2008 ECAR study discovered that students are more interested in peer-to-peer interaction for both social and academic purposes in comparison to peer-to-tutor interaction (Salaway \& Caruso , 2008), highlighting the concept of a 'personal online space'.

Bryant (2007) has highlighted that this mass uptake of social media by students consequently has led to a considerable debate among education researchers and academia. Many are arguing that since these social tools are being employed on a daily basis by the current generation of students entering universities, the integration of these technologies into teaching and learning is something which is expected by this generation of learners who are coined 'digital natives' (Prensky, 2001) or the 'net generation' (Oblinger \& Oblinger, 2005; Tapscott, 2009). This is because they expect to learn using these new technologies and because the aim of higher education should be to prepare them for the requirements of their workplace of the future (Alexander, 2006; Strom \& Strom, 2007, Prensky, 2001). This surge of interest to incorporate these social media tools into education is also a result of their characteristics such as interactivity and collaboration which allow for the co-construction of knowledge in social settings as advocated by the socio-cultural theories of learning (Selwyn et al., 2008). Roblyer, McDaniel, Webb, Herman, \& Witty (2010) in their study looked at faculty $(n=62)$ and student $(n=120)$ uses and perceptions of SNSs in a mid-sized southern university in the United States. Their data showed that students and faculty differ in their current and anticipated use of SNSs where students are more likely to use SNSs and more open towards the instructional use of Facebook or other SNSs to support classroom work compared to faculty who are more likely to use older technologies such as e-mail. This many say would be attributable to the idea of 'digital natives' growing up and being immersed in technology from a very young age, while faculty who are often made up of people much older are 'digital immigrants' (Prensky, 2001) to whom most of these technologies particularly the newer ones are alien.

Nevertheless, in contrast, there are others who point out that caution needs to be exercised against this trend of incorporating technology into teaching and learning just to fulfill the expectations of these students who have grown up using technology in their everyday lives (Kumar, 2010; Kennedy, Judd, Churchward \& Krause, 2008; Oliver and Goerke, 2007). Donnison (2007) for example argued that the ubiquity of these social technologies is an inadequate reason to expect faculty to employ them in teaching and learning. Mason and Rennie (2008) also argued that when evaluating the use of SNSs as either a viable or impractical tool for teaching, educators need to recognize that students' use of SNSs may not always be 'straightforward, steady or predictable'. They argued that students may 
discontinue use of a specific SNS and not become active users after some time, or even change to another SNS. Some research have also highlighted students' concern over academic use of these social media tools in terms of issues of privacy and identity management (Hoare, 2007; Hewitt \& Forte, 2006; Szwelnik, 2008). Additionally, certain research findings seem to indicate that use of SNSs is mainly for social purposes (Boyd \& Ellison, 2007; Lampe et al., 2008; Madge et al., 2009) with some students expressing their unease at the idea of their instructors having a presence in what these students view as their 'private personal space' (Szwelnik, 2008). Sandars and Schroter (2007) found that although students might be familiar with the new technologies for certain purposes, this does not mean that the use of these technologies would be translated into its use for teaching and learning.

\section{Methodology}

The survey instrument used in this study is a 32-item questionnaire. The instrument was previously validated for content and face validity through a pilot involving 37 students at a local university. Additionally, the instrument has also undergone a review process by five experts in educational and social sciences studies. After the pilot survey and expert reviews, the revised questionnaire was administered through the Survey Monkey online survey provider over a period of one and a half month. The respondents $(n=6358)$ are students (both undergraduates and postgraduates) who are studying in institutions of higher learning in Malaysia.

\subsection{Limitations}

A survey is chosen as the method to investigate the guiding question as it is the most suitable method to gather information on behavioral patterns across a large population (Ary et al, 2009). There are problems associated with online surveys, however these problems especially on issues regarding sampling is inherent in other types of surveys as well (Wright, 2005).

\section{Findings}

This section will present the findings based on the focus of the paper which is to discover the respondents' view and use of social networking sites especially in relation to informal learning. As such, only the items immediately relevant to the focus are presented here.

A total of 6358 respondents took the survey during the period when it was administered. $42.2 \%$ of the respondents are males while the rest are females; $88.9 \%$ of them are undergraduate students while the remaining are postgraduate students. Figures 1 to 3 provide the descriptions of the respondents' basic demographic data.

\subsection{Demographics}

Figure 2 shows that technological penetration in terms of ownership of computing devices capable of supporting the needs of a student (computer, laptops or netbooks) is quite high at $97.8 \%$ of the sample population. However, the conventional wisdom in terms of the association between young adults and social networking sites seems to come into question here as shown in Figure 3 where 19.2\% (1922) of the respondents reported not having an account with any social networking sites at the time of the survey. The results are obviously valid for the sample population, and an interesting observation could be made at this point. If the trend continues to be observed by other research or surveys, it could call into question the viability of using social networking sites for the purpose of education especially at the tertiary level. An online system that is not accessible to all learners would be quite useless. This is where the traditional learning management systems used by universities have the advantage as enrolment in the universities would usually mean automatic access to the LMS (Afendi \& Mohamed Amin, 2009). Thus, universities should not simply make it compulsory for students to sign up at social networking sites as these sites are social/personal in nature.

\subsection{Internet Activities}

The respondents were also asked to report on the types of activities that they carried out online in terms of the online activities in which they spend time the most. Figure 4 shows the summary ratings of each activity as rated by the respondents.

As Figure 4 shows, 'Social Networking' is the most highly ranked activity for time spent as reported by the respondents. The second in ranking is 'Learning' while 'Blogging' is last. This shows that the respondents spend their time more on social networking than learning, yet the difference is not that much between the reported time ratings for both activities. It is also possible that both activities are carried out almost simultaneously. The ability to multi-task is something often normally associated with young learners, or the so called 'digital natives'. Beastall (2008) claims that children and young adult learners form close relationship with technology from birth; this supposedly gives them better abilities to utilize technology in quite a different manner from their parents. Veen and Vrakking (2006) coined the term Homo Zappiens to describe the new generations of young learners who according 
to them are able to use the myriad of advantages and flexibility of technology to learn in ways that may be difficult to achieve by the previous generations. This view is however not universally accepted by all researchers; for example, Margaryan and Littlejohn (2009) presented findings that suggest the range of technological tools for learning as used by college students are actually quite limited.

\subsection{Uses for Informal Learning}

The next section discusses how the respondents use social networking sites for the purpose of informal learning. Figure 5 shows the respondents' answers to questions related to informal learning in the survey.

The most noticeable point in Figure 5 is that the majority of respondents make use of SNSs to interact and communicate with their peers for the purpose of informal learning. However, they are almost evenly split on using SNSs to contact their tutors/lecturers for the same purpose. This trend has also been observed in the pilot study for this research where $38 \%$ said 'Yes'. Social networking sites, as the name suggests, are platforms for social interactions. Thus, it may be acceptable to the respondents to connect and communicate with their peers even for the purpose of learning as their peers would be considered a part of their 'social circle'. Things are not so clear cut for their tutors and lecturers, which may explain the almost equal split in terms of use. This trend has also been observed in the literature. Fischman (2008) in his study reported that 39\% of the subjects surveyed would prefer to have regular online discussions with their teachers in SNS. Hewitt and Forte (2006) also reported that two-thirds of their research subjects are 'comfortable' with their teachers' use of Facebook for educational purposes. Chuang and $\mathrm{Ku}$ (2010) reported that $43 \%$ of Facebook users in their study will not add their lecturers as Facebook friends. The numbers may vary from research to research but the fact remains that for some students, SNSs should remain strictly for social use. This is a factor that needs to be taken into account when considering the use of social networking sites and services for educational purposes.

The final item for discussion is their perception on the use of SNSs for the purpose of informal learning (Q28). The purpose of this question is to gauge the respondents' view on the use and effects of SNSs in their lives as students of tertiary institutions.

As can be seen in Figure 6, the majority of the respondents believe that social networking sites are helpful to their lives as students. This is not a surprising finding as it is in line with other research. Yuen and Yuen (2008) reported that students generally have a positive experience in dealing with social networking sites especially for informal learning and collaboration with their peers.

Figure 7 shows that about $60 \%$ of the respondents do not believe that social networking affect their academic performance. A much publicized report by Karpinski (2009) seems to suggest a relationship between the use of Facebook and low grades. However, a more systematic research by Pasek, More and Hargittai (2009) found the opposite to be true; that higher-grade students use Facebook more compared to the lower-grade students. They reported that Facebook use does not seem to be an indicator of academic performance. While these studies do not offer any clear cut relationship on the negative impacts of SNSs on academic performance, there are various studies that have documented the effects of internet addiction on social and academic development of young adults (Chen and Peng, 2008). However, it must also be noted that young adults use the internet for a variety of purposes and activities, and any of these could be a cause for 'internet addiction'.

Based on the data displayed in Figure 8, about $42 \%$ of the respondents agree that they spend more time on SNSs for socializing. $36 \%$ disagreed and $21.9 \%$ selected 'Unsure' to the statement. The respondents appear to be almost equally split on this statement. SNSs are designed for social purposes; therefore, it is not surprising that while some students would employ it for learning, others would not. 'Technological affordance' is the term used to describe situations where users adapt a technology for a purpose other than it was originally designed for. Anderson (2004) describes the greatest affordance that the web confer to education is its ability to deeply enhance communication and interaction between people. It is only to be expected that social-oriented web applications be adapted for other purposes including education.

Figure 9 shows that the majority of respondents (61\%) find it more convenient to use SNSs for discussion. The reason could lie in the fact that most SNSs are designed to enhance interaction, communication and sharing between users; therefore, the communication tools and environments of SNSs are much more conducive than what could be normally found in learning management systems (LMS) used in Malaysian universities.

\section{Conclusion}

This paper has presented the results of a survey on Malaysian university students' perception and use of SNSs for the purpose of informal learning. The results indicate that the respondents do make use of SNSs for activities that are common for informal learning i.e. communicating with peers and arranging for meetings and many others. 
Furthermore, as to be expected within the normal definition of informal learning, the respondents are less willing to contact their lecturers compared to their peers. The respondents also have a positive view of social networking and its effects on their lives as students. The conclusion that can be drawn from this survey seems to be similar with Selwyn (2007), in that students' use of social networking sites and services is usually centered on the informal aspects of education. However, it is important for the educators to remember that even within strictly traditional institutions of higher learning, the informal aspects of learning is still very much important. It is within this context that the role of SNSs should be recognized and perhaps subtly, and non-intrusively, enhanced to further educational goals. Further research could be carried out to look at other issues such as whether SNSs could play a role in formal learning (or even if it should be used for that purpose

\section{References}

Afendi Hamat \& Mohamed Amin Embi. (2009). Course management systems: research, design \& development. Karisma Publishing Sdn Bhd: Shah Alam, MY.

Alexander, B. (2006). Web 2.0: A new wave of innovation for teaching and learning? EDUCAUSE Review, 41, 32-44.

Anderson, T. (2004). Toward a theory of online learning. In T. Anderson \& F. Elloumi (Eds.), Theory and practice of online learning (pp.33-60). Athabasca, AB: Athabasca University. [Online] Available: http://cde.athabascau.ca/online_book/ch2.html (June 23, 2011)

Ary, D., Jacobs, C.J., Razavieh, A., \& Sorenson C.K. (2009). Introduction to research in education (8 ${ }^{\text {th }}$ ed). Wadsworth Publishing.

Beastall, L. (2008). Enchanting a disenchanted child: Revolutionizing the means of education using information and communication technology and e-learning. British Journal of Sociology of Education, 27(1), 97-110. http://dx.doi.org/10.1080/01425690500376758

Boyd, D. M., \& Ellison, N. B. (2007). Social Network Sites: Definition, history and scholarship. Journal of Computer Mediated Communication, 13(1), 210-230. [Online] Available: http://jcmc.indiana.edu/vol13/issue1/boyd.ellison.html (January 12, 2011)

Bryant, L. (2007). Emerging trends in social software for education. British Educational Communications and Technology Agency. Coventry: Becta.

Chen, Y.F., \& Peng, S. S. (2008). University students' Internet use and its relationships with academic performance, interpersonal relationships, psychosocial adjustment, and self-evaluation. Cyberpsychology and Behavior, 11(4), 467-469. [Online] Available: http://www.ncbi.nlm.nih.gov/pubmed/18721095 (May 3, 2011)

Chuang, H.Y., \& Ku, H.Y. (2010). Users' attitudes and perceptions toward online social networking tools. In D. Gibson \& B. Dodge (Eds.), Proceedings of Society for Information Technology \& Teacher Education International Conference 2010 (pp. 1396-1399). Chesapeake, VA: AACE.

Dalsgaard, C. (2008). Social networking sites: Transparency in online education. EUNIS 2008 VISION IT - Vision for IT in higher education. Helsingforsgade, Denmark: Institute of Information and Media Studies, University of Aarhus, June 25, 2008. [Online] Available: http://eunis.dk/papers/p41.pdf. (October 30, 2010)

Donnisson, S. (2007). Digital generation pre-service teachers as change agents: a paradox. Australian Journal of Teacher Education, 32(4), 1-12. [Online] Available: http://ajte.education.ecu.edu.au/issues/PDF/324/Donnison.pdf (February 2, 2011)

Ferdig, R.E. (2007). Editorial: Examining Social Software in Teacher Education. Journal of Technology and Teacher Education, 15(1), 5-10. Chesapeake, VA: AACE. [Online] Available: http://www.editlib.org/p/23518 (May 3, 2011)

Fischman, J. (2008). Dear Professor, students want to chat with you. The Chronicle of Higher Education. [Online] Available: http://chronicle.com/wiredcampus/article/3384/dear-professor-students-want-to-chat-with-you (October 15, 2008)

Hewitt, A., \& Forte, A. (2006). Crossing boundaries: Identity management and student/faculty relationships on the Facebook. Presented at the Computer Supported Cooperative Work Conference, Banff, Alberta, Canada. [Online] Available:

http://www.mendeley.com/research/crossing-boundaries-identity-management-and-studentfaculty-relationships-on-t he-facebook-2/ (February 2, 2011)

Hoare, Stephen. (2007). Students tell universities: Get out of MySpace! Guardian, 5 November. [Online] Available: http://www.guardian.co.uk/education/2007/nov/05/link.students (January 2, 2011) 
Jones, S., \& Madden, M. (2002) The Internet goes to college: How students are living in the future with today's technology. Pew Internet and American Life Project Washington, D.C. Sept. 15, 2002. Pew Research Center, Washington, D.C.

Karpinski, A.C. (2009). A description of Facebook use and academic performance among undergraduate and graduate students. Paper presented at the Annual Meeting of the American Educational Research Association, San Diego, Calif. U.S.A.

Kennedy, G.E., Judd, T.S., Churchward, A., \& Krause, K. (2008). First year students' experiences with technology: Are they really digital natives? Australasian Journal of Educational Technology, 24(1): 108-122. [Online] Available: http://www.ascilite.org.au/ajet/ajet24/kennedy.pdf (January 12, 2011)

Kumar, S. (2009). Undergraduate perceptions of the usefulness of Web 2.0 in higher education: Survey development. In D. Remenyi (Ed.), The Proceedings of the 8th European Conference on e-Learning. University of Bari, Italy 29-30 October 2009. (pp. 308-315). Italy: University of Bari.

Kvavik, R. B., \& Caruso, J.B. (2005). ECAR study of students and information technology, 2005: Convenience, connection, control, learning. Andine] Available: http://connect.educause.edu/Library/Abstract/ECARStudyofStudentsandInf/41159 (January 3, 2011)

Lampe, C., Ellison, N., \& Steinfield, C. (2008). Changes in use and perception of Facebook. In Proceedings of the 2008 Conference on Computer-Supported Cooperative Work (CSCW 2008). [Online] Available: https://www.msu.edu/ nellison/LampeEllisonSteinfield2008.pdf (February 12, 2011)

Lenhart, A., \& Madden, M. (2007). Social networking websites and teens: An overview. Pew Internet and American Life Project Report. [Online] Available: http://www.pewinternet.org/PPF/r/198/report_dispaly.asp (February 12, 2011)

Madge, C., Meek, J., Wellens, J., \& Hooley, T. (2009). Facebook, social integration and informal learning at university: It is more for socialising and talking to friends about work than for actually doing work. Learning, Media and Technology, 34 (2), $141 \quad-\quad 155 . \quad$ [Online] Available: http://www.informaworld.com/smpp/section?content=a912648077\&fulltext=713240928 (January 2, 2011)

Maloney, E. (2007). What Web 2.0 can teach us about learning? The Chronicle of Higher Education, 53 (18), January $5^{\text {th }}$, p. B 26. [Online] Available: http://chronicle.com/article/What-Web-20-Can-Teach-Us/8332 (February 2, 2011)

Margaryan, A., \& Littlejohn, A. (2009). Are digital natives a myth or reality? Students' use of technologies for learning. [Online]

Available:

http://www.academy.gcal.ac.uk/anoush/documents/DigitalNativesMythOrReality-MargaryanAndLittlejohn-draft-11 1208.pdf (February 2, 2011)

Mason, R., \& Rennie, F. (2008). E-Learning and Social Network Handbook: Resources for Higher Education. Madison Ave, New York: Routledge.

Oblinger, D., \& Oblinger, J. (2005). Is it age or IT: First steps towards understanding the net generation. In D. Oblinger \& J. Oblinger (Eds.), Educating the Net generation (pp. 2.1-2.20). Boulder, Colorado: EDUCAUSE. [Online] Available:http://www.educause.edu/educatingthenetgen (March 30, 2011)

Oliver, B., \& Goerke, V. (2007). Australian undergraduates' use and ownership of emerging technologies: Implications and opportunities for creating engaging learning experiences for the Net Generation. Australasian Journal of Educational Technology, 23(2), 171-186. [Online] Available: http://www.ascilite.org.au/ajet/ajet23/oliver.html (April 2, 2011)

Pasek, J., More, E., \& Hargittai, E. (2009). Facebook and academic performance: Reconciling a media sensation with data. First Monday 14(5). [Online] Available: http://firstmonday.org/htbin/cgiwrap/bin/ojs/index.php/fm/article/view/2504/2187 (January 2, 2011)

Pence, H. E. (2007). Preparing for the real web generation. Journal of Educational Technology Systems, 35(3), 347-356. http://dx.doi.org/10.2190/7116-G776-7P42-V110

Prensky, M. (2001). Digital natives, digital immigrants. On the Horizon, 9(5). [Online] Available: http://www.marcprensky.com/writing/prensky\%20-\%20digital\%20natives,\%20digital\%20immigrants\%20-\%20part1 .pdf (February 12, 2011)

Roblyer, M.D., McDaniel, M., Webb, M., Herman, J., \& Witty, J.C. (2010). Findings on Facebook in higher education: A comparison of college faculty and student uses and perceptions of social networking sites. The Internet 
and Higher Education, 13(3): 134-140. http://dx.doi.org/10.1016/j.iheduc.2010.03.002

Salaway, G., \& Caruso, J.B. (2008). The ECAR study of undergraduate students and information technology, 2008. ECAR Research 17 Study 8. Boulder, Colorado: EDUCAUSE Center for Applied Research. [Online] Available: http://net.educause.edu/ir/library/pdf/ERS0808/RS/ERS0808w.pdf (February 12, 2011)

Sandars, J., \& Schroter, S. (2007). Web 2.0 Technologies for Undergraduate and Postgraduate Medical Education: An Online Survey. Postgraduate Medical Journal, 83, 759-762. [Online] Available: http://www.ncbi.nlm.nih.gov/pmc/articles/PMC2750915/ (April 5, 2011)

Schwartz, H.L. (2009). Facebook: The new classroom commons? The Chronicle of Higher Education. B13. [Online] Available: http://gradstudies.carlow.edu/pdf/schwartz-chronicle_9-28-09.pdf (March 21, 2011)

Selwyn, N. (2007). 'Screw Blackboard ... do it on Facebook!' An investigation of students' educational use of Facebook. Paper given at Poke 1.0: Facebook social research symposium. London, 15 November 2007. [Online] Available: http://www.lse.ac.uk/collections/informationSystems/newsAndEvents/2008events/selwynpaper.pdf (February 2, 2011)

Selwyn, N., Crook, C., Carr, D., Carmichael, P., Noss, R., \& Laurillard, D. (2008). Education 2.0? Designing the web for teaching and learning. Teaching and Learning Research Programme. [Online] Available: http://www.tlrp.org/tel/files/2008/11/tel_comm_final.pdf (February 12, 2011)

Simões, Luís, \& Borges Gouveia, Luís. (2008). Web 2.0 and Higher Education: Pedagogical Implications. Proceedings of the 4th International Barcelona Conference on Higher Education, Vol. 2. Knowledge technologies for social transformation. Barcelona: GUNI. [Online] Available: http://ufp.academia.edu/LuisGouveia/Papers/330783/Web_2.0_and_Higher_Education_Pedagogical_Implications (April 2, 2011)

Strom, R.D., \& Strom, P.S. (2007). New Directions for Teaching, Learning, and Assessment. Netherlands: Springer Verlag.

Szwelnik, Alice. (2008). Embracing the Web 2.0 culture in business education: The new face of Facebook. The Higher Education Academy, BMAF Subject Centre. [Online] Available: http://www.heacademy.ac.uk/assets/bmaf/documents/projects/TRDG_projects/trdg_0708/finalreports_0708/Alice_S zwelnik_OBU_web.doc (February 12, 2011)

Tapscott, D. (2009). Grown up digital: How the net generation is changing your world. New York: McGraw-Hill.

Veen, W., \& Vrakking, B. (2006). Homo Zappiens: Growing Up in a Digital Age. London: Network Continuum Education.

Wright, K. B. (2005). Researching Internet-based populations: Advantages and disadvantages of online survey research, online questionnaire authoring software packages, and web survey services. Journal of Computer-Mediated Communication, 10(3), article 11.

Yuen, S.C.Y., \& Yuen, P. (2008). Social networks in education. In C. Bonk et al. (Eds.), Proceedings of World Conference on E-Learning in Corporate, Government, Healthcare, and Higher Education 2008 (pp. 1408-1412). Chesapeake, VA: AACE. 


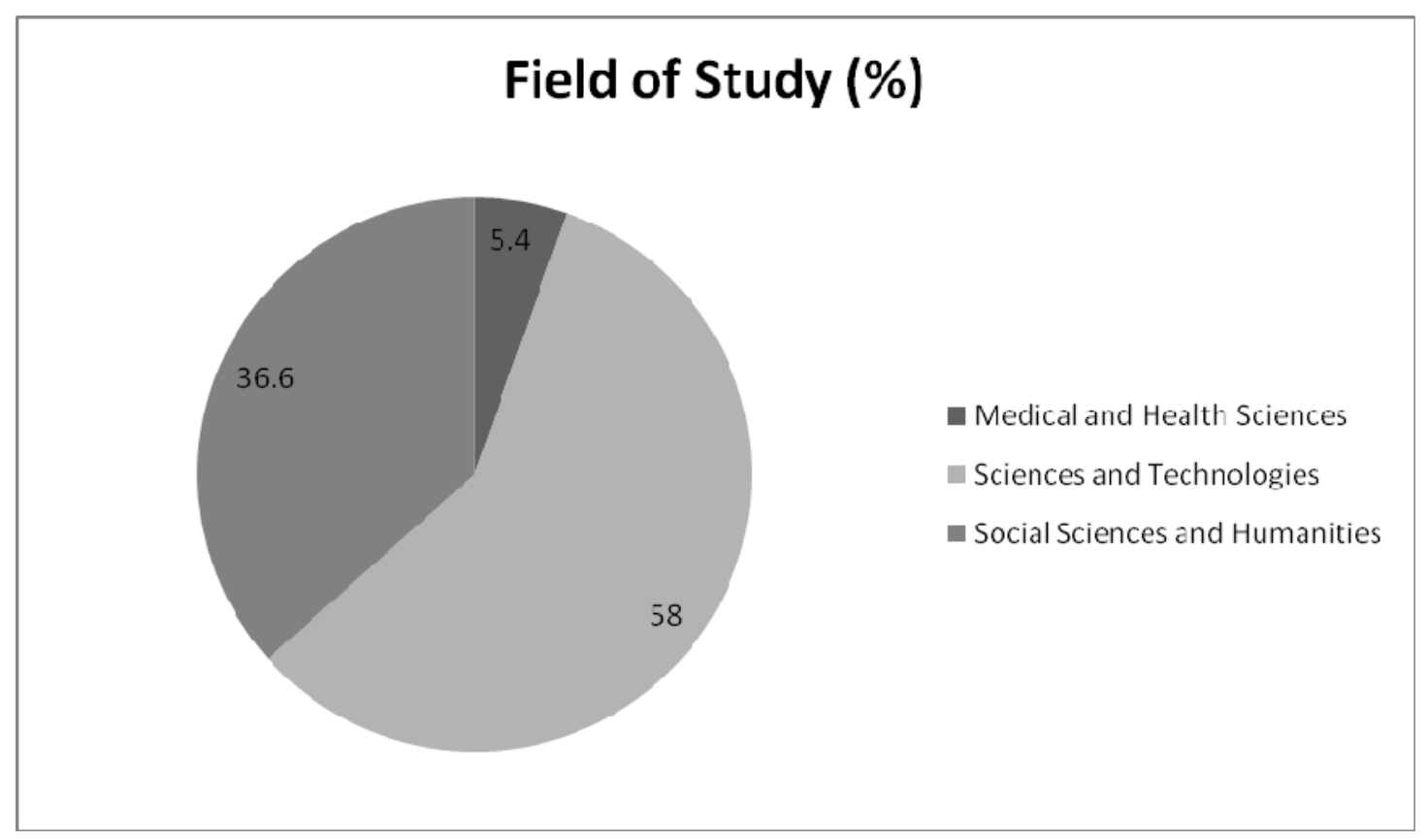

Figure 1. Field of Studies

\section{Ownership of Computer/Laptop/Notebook}

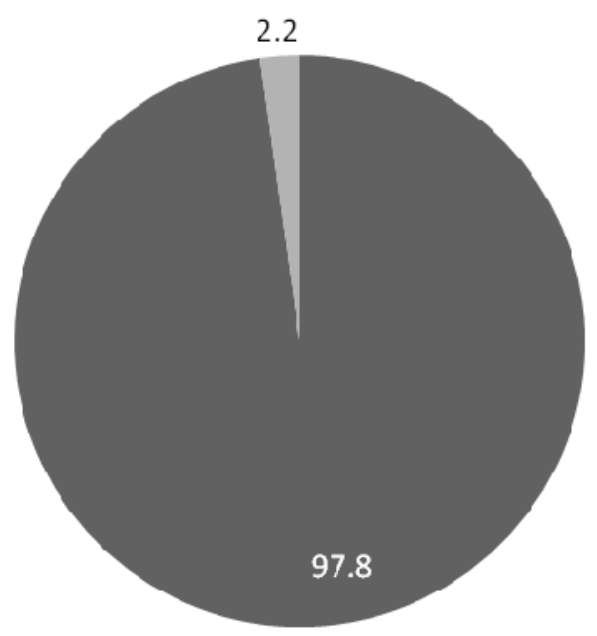

Figure 2. Ownership of Computer/Laptop/Netbook 


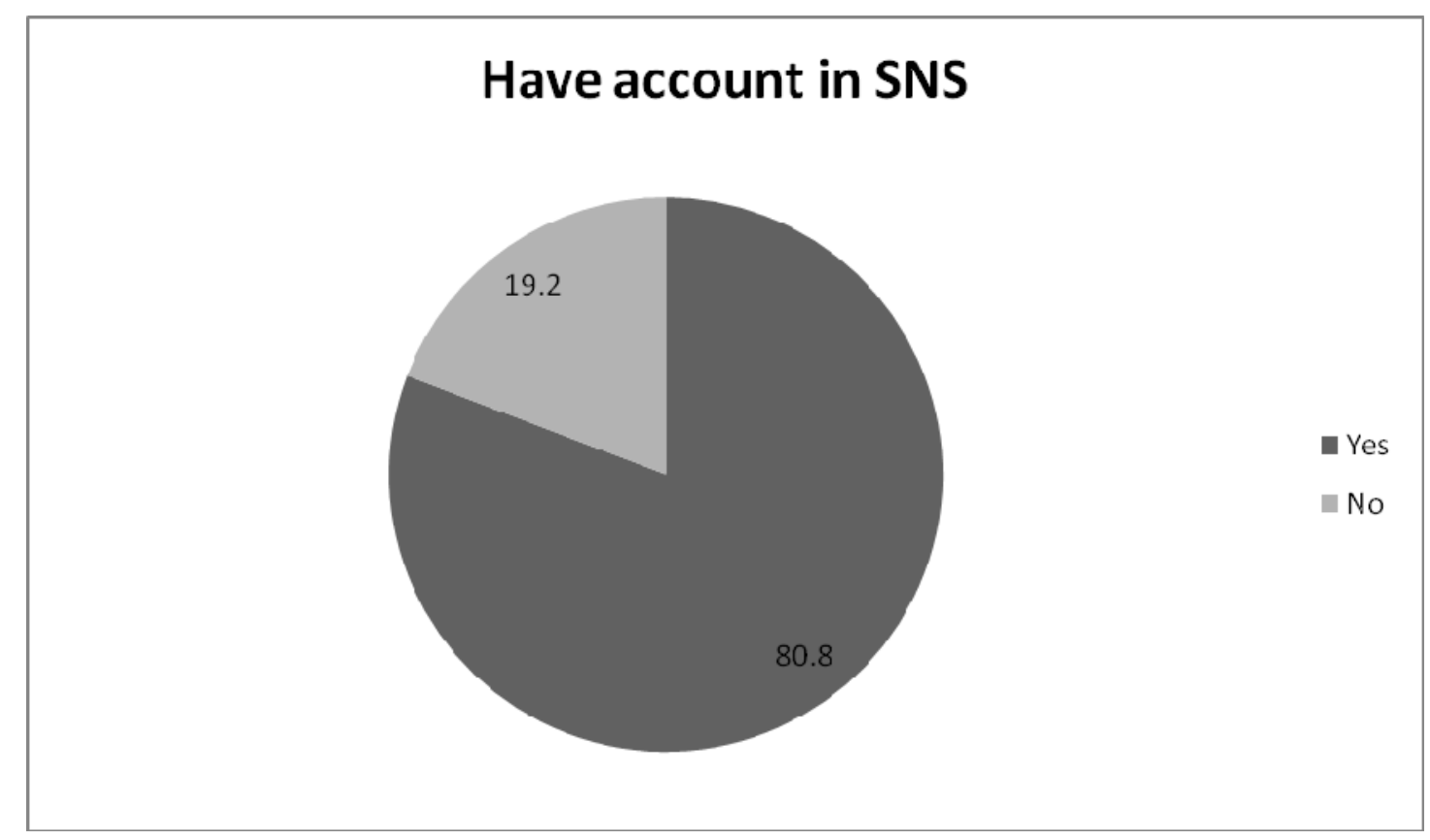

Figure 3. Accounts in SNS

\begin{tabular}{|l|c|c|c|c|c|c|}
\hline & Emailing & Social Networking & Leaming & Gaming & Chatting & Blogging \\
\hline N Valid & 6358 & 6358 & 6358 & 6358 & 6358 & 6358 \\
& 0 & 0 & 0 & 0 & 0 & 0 \\
Missing & & 4.0120 & 3.8289 & 1.9374 & 2.8301 & 1.8723 \\
\hline Mean & 3.3430 & 4.0000 & 4.0000 & 1.0000 & 3.0000 & 1.0000 \\
\hline Median & 3.0000 & 5.00 & 4.00 & 1.00 & 3.00 & 1.00 \\
\hline Mode & 5.00 & 1.22793 & 1.00195 & 1.929 & 1.38661 & 1.46138 \\
\hline $\begin{array}{l}\text { Std. } \\
\text { Dev. }\end{array}$ & 1.33578 & & & & & \\
\hline
\end{tabular}

Figure 4. Q12: Rate the following online activities in terms of time you spend most. 


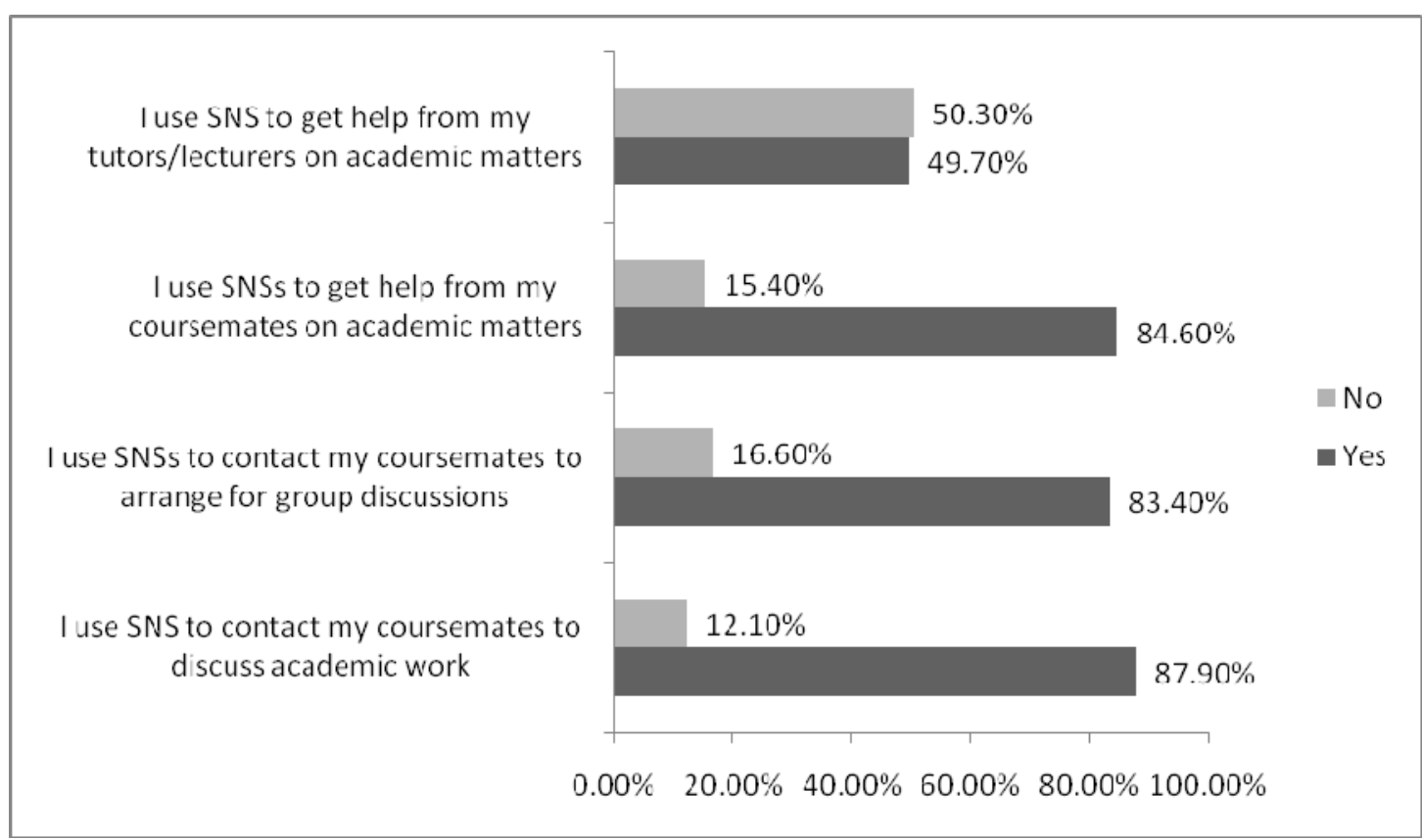

Figure 5. Responses to the use of SNSs for informal learning

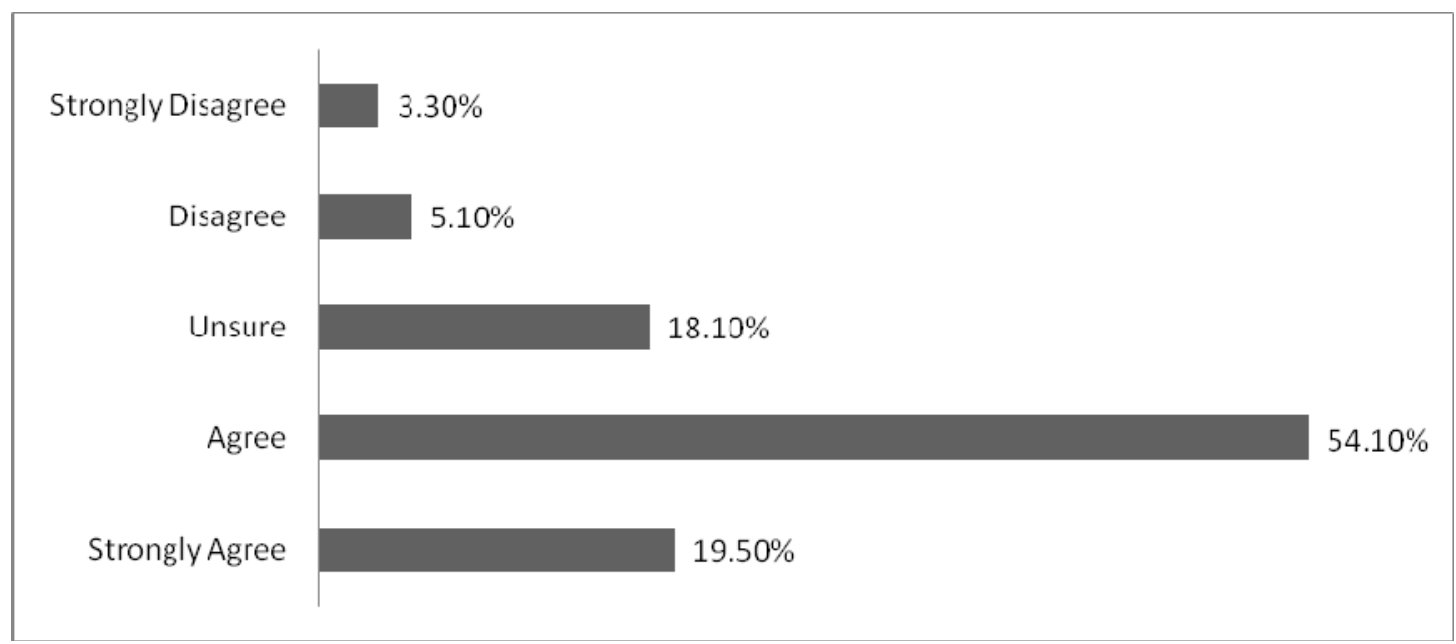

Figure 6. Q28(i) SNSs are helpful to my academic life as a student. 


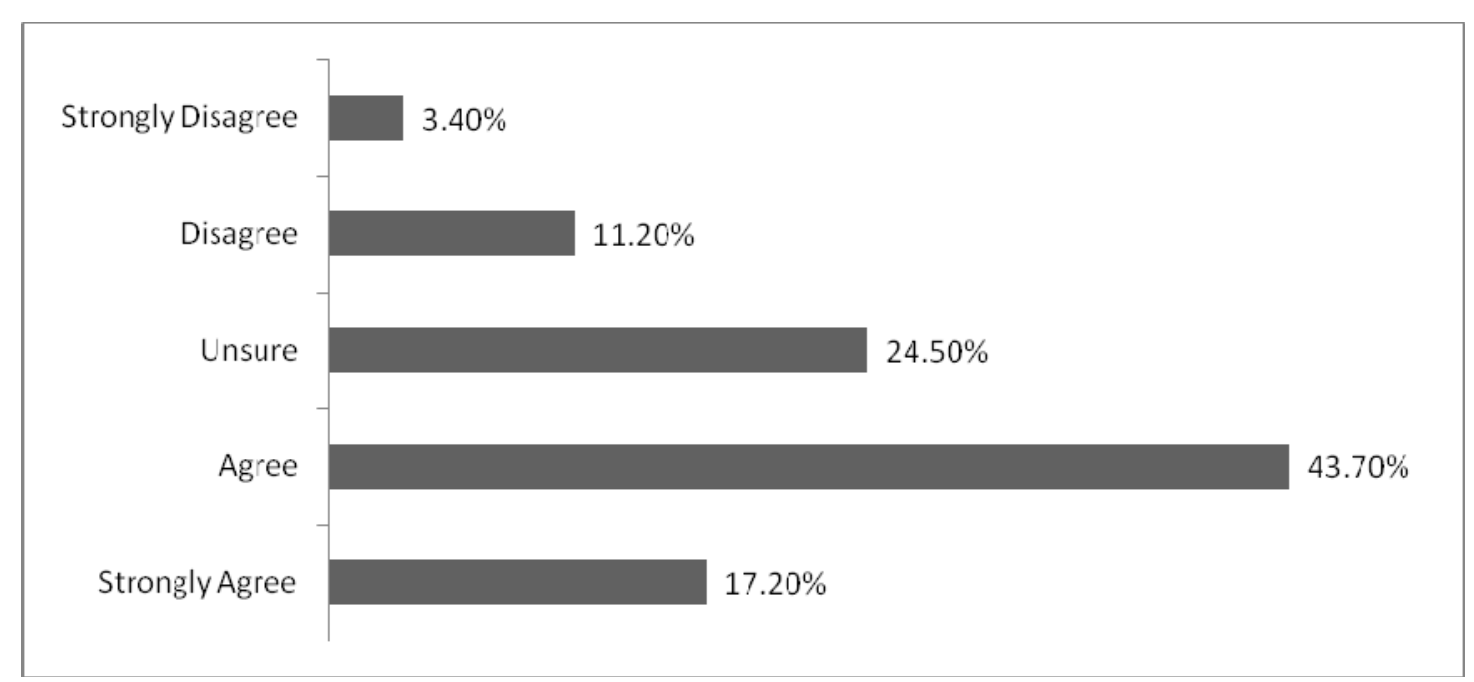

Figure 7. Q28(ii). Using SNSs does not affect my academic performance

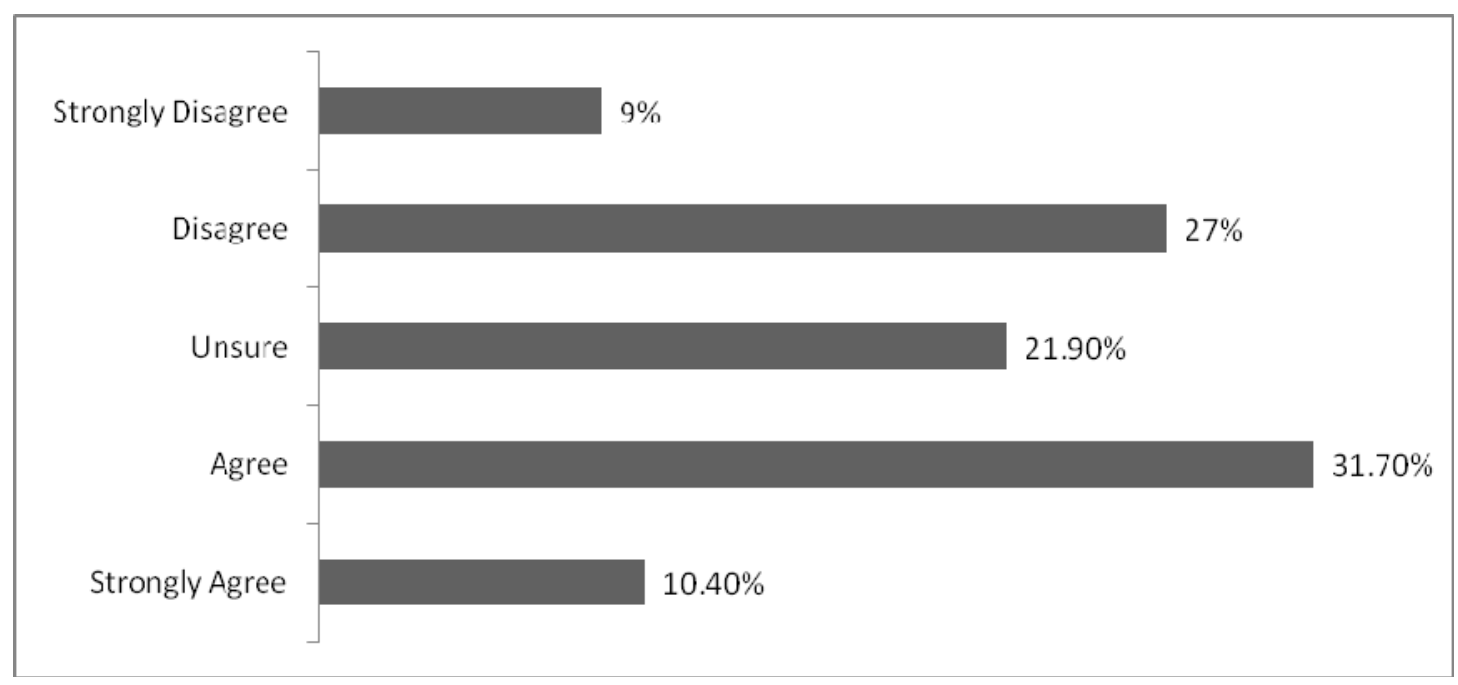

Figure 8. Q28(iii). I spend more time socializing on SNSs rather than for academic work.

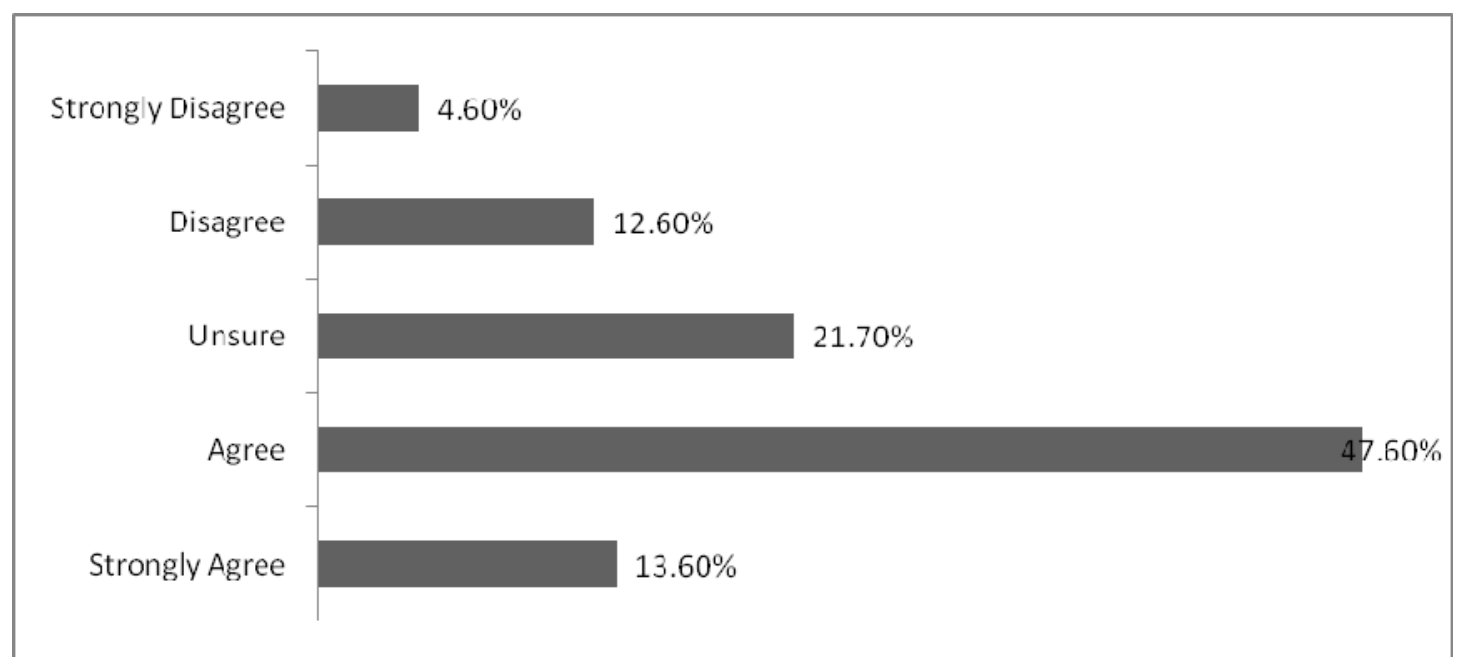

Figure 9. Q28(iv). I find that it is more convenient to discuss course matters through SNSs with my friends. 